\title{
A protocol to assess cell cycle and apoptosis in human and mouse pluripotent cells
}

\author{
Michael J Edel ${ }^{1,2,3}$, Cristina Menchon', Jose Miguel Andres Vaquero ${ }^{1}$ and Juan Carlos Izpisua Belmonte ${ }^{1,4^{*}}$
}

\begin{abstract}
Embryonic stem cells (ESC) and induced pluripotent stem cells (iPSCs) present a great opportunity to treat and model human disease as a cell replacement therapy. There is a growing pressure to understand better the signal transduction pathways regulating pluripotency and self-renewal of these special cells in order to deliver a safe and reliable cell based therapy in the near future. Many signal transduction pathways converge on two major cell functions associated with self-renewal and pluripotency: control of the cell cycle and apoptosis, although a standard method is lacking across the field. Here we present a detailed protocol to assess the cell cycle and apoptosis of ESC and iPSCs as a single reference point offering an easy to use standard approach across the field.
\end{abstract}

\section{Introduction}

Human embryonic stem cells (hESC) have been derived from the inner cell mass of blastocytes and can be maintained in vitro indefinitely with the addition of fibroblastic growth factor 2 (FGF2) [1]. It has been shown that a combination of three or four pluripotency transcription factors; Oct4, Sox 2 and KLf4, with or without Myc can reprogram somatic cells to generate induced pluripotent stem cells (iPSC) $[2,3]$. Recently, it has been shown that loss of p53 function can enhance the efficiency of reprogramming, suggesting that the cell cycle is a rate limiting step in the reprogramming process [4-10]. Given the important role of the cell cycle and apoptosis in pluripotent cells, a detailed protocol that standardises the technique of measuring cell cycle and apoptosis in pluripotent cells across the field is called for.

The cell cycle of mouse ESCs and to a lesser extent hESCs has been well described [11-13]. The cell cycle regulatory machinery of ESC including the Cyclin families A, E, D, and B and their kinases CDK2, 4 and 6 , are not regulated in a cyclic fashion, with the exception of cyclin B $[11,12]$. Of the core machinery, cyclin $\mathrm{A} / \mathrm{E} / \mathrm{CDK} 2$ are regarded as constitutively on in mouse ESC driving an almost non-existent $\mathrm{G}_{1}$ phase into $\mathrm{S}$ phase, in which $60-70 \%$ of ESC are present. Consequently, the rate of ESC proliferation is much faster

\footnotetext{
* Correspondence: belmonte@salk.edu

${ }^{1}$ Center of Regenerative Medicine in Barcelona, Dr. Aiguader 88, 08003 Barcelona, Spain

Full list of author information is available at the end of the article
}

with an average cycle lasting just twelve hours compared to somatic cells $[13,14]$. A recent study functionally demonstrated that Cyclin A regulates pluripotency but is redundant in fibroblasts suggesting it is a pluripotent associated cell cycle kinase [15]. Many of the peripheral genes that control cell cycle such as $16^{\mathrm{INK} 4 \mathrm{a}}$ are thought to be inactive, resulting in a different regulation of cell cycle in mouse ESC [16]. It is evident that there are many differences between somatic and pluripotent cells; however, little is known about the role of the cell cycle in maintaining ESC or iPSC in culture. Much less is known about control of apoptosis in ESC or iPSC while under in vitro conditions.

Here we describe a protocol how to measure cell cycle and apoptosis in pluripotent stem cells (hESC and iPS cells) that could be used, for example, following infection with a lentivirus to manipulate cell cycle function of ESC or iPSC in vitro. Detailed protocols how to make lentivirus have been published previously [17-19]. We describe a standard method to measure cell cycle profile by FACs in hESC and iPS cells using EdU substrate; and apoptosis using DilC mitochondrial membrane method in the same sample concurrently. The use of DNA dyes and EdU staining (an advance on BRDU staining) has been discussed extensively by Cappella et al and Hamelik et al $[20,21]$. In addition we describe a list of working antibodies for cell cycle and apoptosis proteins by western blot methodology. The protocol described here is applicable to any human or animal pluripotent stem cell and enables "getting the most" from your cell cycle and 
apoptosis analyses, offering an easy to reference, comprehensive standardised protocol across the field of pluripotent stem cells.

\section{Materials}

For detailed methods on how to make iPSCs as well as how to infect such cells using concentrated lentiviruses and supernatant retroviruses including reagents, equipment and set up please refer to recently published work [17-19].

\section{Reagents}

- Human and mouse embryonic stem cells (ESC)

CAUTION: Check ethic issues with your specific institute for use of hESC.

- Human or mouse induced pluripotent stem cells (iPSC)

- Mitotically inactivated mouse embryonic fibroblasts (irMEFs)

- Mitotically inactivated human foreskin fibroblasts (irHFFs) (ATCC, cat. no. CRL-2429)

- $0.1 \%(\mathrm{wt} / \mathrm{vol}$ ) Gelatin solution (Millipore, cat. no. ES006-B)

- Matrigel (Mg, BD Biosciences, cat. no. 356234)

- Dulbecco's PBS, without $\mathrm{Ca} 2+$ or $\mathrm{Mg} 2+$ (PAA laboratories $\mathrm{GmbH}$, cat. no. H15-002)

- DMEM (Invitrogen, cat. no. 21969-035)

- KO-DMEM (Knockout DMEM, Invitrogen, cat. no. 10829-018)

- Fetal calf serum (FCS, Perbio, Hyclone, cat. no. CH30160.03)

- Heat-inactivated fetal bovine serum (FBS, Invitrogen, cat. no. 10270-106)

- Knockout Serum Replacement (KO-SR, Invitrogen, cat. no. 10828-028)

- Trypan Blue stain (Invitrogen, cat. no. 15250-061)

- $20 \%$ (wt/vol) Human serum albumin (HSA, Instituto Grifols SA, cat. no. 670612)

- GlutaMAX (Invitrogen, cat. no. 35050-038)

- Minimum essential medium Eagle's nonessential amino acids, $100 \times$ (Lonza, cat. no. BE13-114E)

- Nucleosides, $100 \times$ (Millipore, cat. no. ES-008-D)

- Penicillin/streptomycin (Invitrogen, cat. no. 15140163)

- Lipofectamine 2000 (Invitrogen)

- $50 \mathrm{mM}$ 2-mercaptoethanol (Invitrogen, cat. no. 31350-010)

- Basic fibroblast growth factor (Peprotech cat. no. 100-18B) (see REAGENT SETUP)

0.25\% (wt/vol) Trypsin/EDTA (Invitrogen, cat. no. 25200-056)

0.05\% (wt/vol) Trypsin/EDTA (Invitrogen, cat. no. 25300-054)
- Polybrene (10 mg ml-1, Millipore, cat. no. TR-1003G)

- FuGENE 6 transfection reagent (Roche Applied Science, cat. no. 11988387 001)

- DMSO (Sigma, cat. no. D4540)

- MitoProbe DilC assay kit for flow cytometry (M34151)

- Invitrogen Click iT Edu cell proliferation assay kit for flow cytometry (A10202).

\section{Equipment}

- DakoCytomation MoFlo High-performance cell sorter equipped with 3 lasers, an Innova 90C UV laser from Coherent, a red diode $635 \mathrm{~nm}$ and a Lytcyt200s $488 \mathrm{~nm}$ solid-state laser. The PMT detectors used are Hamamatsu -15.

- Leica SP5 AOBS confocal microscope

- Water Bath set to $37^{\circ} \mathrm{C}$.

- Class-II cabinet with aspirator for tissue culture (Telstar Bio-II-A)

- Class-II cabinet with space for stereomicroscope (Telstar Bio-II-A/G)

- Aspirator tube assembly (Sigma, cat. no. A5177)

- Stereomicroscope (Olympus SZX12, Olympus)

- Low-end color video camera (JVC TKC1481BEG)

- Low-end 8-inch LCD display (BOMAN TV304)

- Inverted tissue culture microscope with phase contrast and epifluorescence, with $\times 5, \times 10, \times 20$ and $\times 40$ objectives (Leica DMIL, Leica)

- Thermostatized tissue culture centrifuge and swinging rotor with adapters for $15-\mathrm{ml}$ and $50-\mathrm{ml}$ tubes and microplates (Beckman Coulter Allegra X-12R centrifuge with SX4750A rotor, Beckman Coulter)

- High-speed centrifuge and swinging rotor (Beckman Coulter Avanti J-30I centrifuge with JS-24.38 rotor, Beckman Coulter)

- Cell culture incubator set at $37^{\circ} \mathrm{C}, 5 \% \mathrm{CO} 2$ (REVCO, cat. no. RCO3000D-9-VBC)

- Cell culture incubator set at $32^{\circ} \mathrm{C}, 5 \% \mathrm{CO} 2$ (REVCO, cat. no. RCO3000D-9-VBC)

- Cell culture incubator set at $37^{\circ} \mathrm{C}, 5 \% \mathrm{CO} 2$ and $5 \%$ O2 (REVCO, cat. no. RTG5000D-9-VBC)

- Microcentrifuge (Eppendorf 5424, Eppendorf)

- Tissue culture dish, 100 and $150 \mathrm{~mm}$

- Tissue culture flasks, T75 and T150

- Tissue culture plates, six-well

- Conical tubes, 15 and $50 \mathrm{ml}$

- Screw-cap microcentrifuge tubes (Sarstedt, cat. no. 72.692.005)

- Polyallomer centrifuge tubes, $13 \times 51 \mathrm{~mm}$ (Beckman, cat. no. 326819)

- Cover slips

- Stripper micropipette (Mid Atlantic, cat. no. MXL3STR) 
- Stripper tips, 150 uM (REF MXL3-150) ORIGIO mid-atlantic devices.

- Cryo $1^{\circ} \mathrm{C}$ Freezing Container, 'Mr. Frosty' (Nalgene, cat. no. 5100-0001)

- Slide flask (Nunc, cat. no. 170920)

- Bottle-top filter system $0.22 \mu \mathrm{m}, 500 \mathrm{ml}$ (Millipore, cat. no. SCGPU05RE)

- Filter, Mille-HV PVDF (polyvinylidene fluoride) (0.45 $\mu \mathrm{m}$, Millipore, cat. no. SLHV033RS)

- Invitrogen western blot and transfer equipment.

\section{REAGENT SETUP}

\section{Basic fibroblast growth factor (bFGF)}

After spinning briefly, resuspend the contents of the vial with $10 \mathrm{ml}$ of $0.2 \%$ (wt $/ \mathrm{vol}$ ) HSA in PBS. The final concentration of bFGF is $100 \mu \mathrm{g} / \mathrm{ml}$. Prepare $50 \mu \mathrm{l}$ and 100 $\mu \mathrm{l}$ aliquots in screw-cap microcentrifuge tubes and store at minus $20^{\circ} \mathrm{C}$ for up to 6 months. Avoid more than three freeze thaw cycles.

\section{$10 \mathrm{mM}$ EdU solution}

Add $4 \mathrm{ml}$ of DMSO to EdU substrate, mix well and aliquot into $50 \mathrm{ul}$ batches and store at $-20 \mathrm{C}$.

\section{Saponin based wash buffer}

Add $1 \mathrm{ml}$ of Saponin from Click iT kit to $9 \mathrm{mls}$ of PBS for working buffer.

\section{DAPI solution}

CAUTION: DAPI is a known mutagen and should be handled with care. The dye must be disposed of safely and in accordance with applicable local regulations.

0,1M Tris Base pH7,4 (from Sigma ref. T1503; MW = 121.14)

$0,9 \%$ or $150 \mathrm{mM} \mathrm{NaCl}$ (from Sigma ref. S3014; $\mathrm{MW}=$ 58.44)

$1 \mathrm{mM} \mathrm{CaCl} 2$ (from Sigma ref. C2661; MW = 110.986)

$0.5 \mathrm{mM} \mathrm{MgCl} 2$ (from Merk ref. 1.05833.1000; $\mathrm{MW}=$ 203.30) - 6H2O

0.2\% BSA (from Sigma ref. A4503)

0.1\% Nonidet P40 (from Sigma ref. I8896) - Igepal

$10 \mu \mathrm{g} / \mathrm{mL}$ DAPI (from Invitrogen ref. D21490)

Propidium lodide (P4170, Sigma-Aldrich) solution $(0.5 \mathrm{mg} / \mathrm{ml}$ in $\mathrm{PBS}$ with $0.1 \%$ sodium azide, $\mathrm{pH}$ approximately 7.4)

\section{BOX 1}

HES media (for culture of hESc and hIPSC on ir MEF or irHFF feeder layers)

-Knockout DMEM (Gibco \#10829-018) (4으.

-Knockout Serum Replacement (KSR) (Gibco \#10828-028) $\left(-20^{\circ} \mathrm{C}\right)$.

- Non-Essetial Amino Acids 100× (Gibco) $\left(4^{\circ} \mathrm{C}\right)$.
-2-Mercaptoethanol $50 \mathrm{mM}$ (Gibco \#31350-010) (4 C).

-Penicillin (10.000U/ml)/Streptomycin $(10.000 \mu \mathrm{g} /$ ml) (100X).

(Gibco \#15140-122) (-20 $\left.{ }^{\circ} \mathrm{C}\right)$.

-GlutaMAX 200 mM (100X) (Gibco \#35050-038) $\left(-20^{\circ} \mathrm{C}\right)$.

- basic Fibroblastic Growth factor $100 \mu \mathrm{g} / \mathrm{ml}$ (Peprotech) $\left(-20^{\circ} \mathrm{C}\right) .250 \mathbf{~ m l}$

-Knock-Out DMEM $\quad 193,5 \mathrm{ml}$

$-20 \%$ Knock-Out serum replacement $50 \mathrm{ml}$

$-1 \times$ Non-Essetial Amino Acids 2,5 ml

$-50 \mathrm{U} / \mathrm{ml}-50 \mu \mathrm{g} / \mathrm{ml}$ Penicillin/Streptomycin (P/

S) $1,25 \mathrm{ml}$

-1× GlutaMAX 2,5 ml

$-50 \mu \mathrm{M}$ 2-Mercaptoethanol $250 \mu \mathrm{l}$

$-8 \mathrm{ng} / \mathrm{ml}$ basic Fibroblastic Growth factor $20 \mu \mathrm{l}$

HUES media (for culture of hESC or hiPSC independent of feeder layers on matrigel)

-Knockout DMEM (Gibco \#10829-018) ( $4^{\circ} \mathrm{C}$ ).

-Knockout Serum Replacement (KSR) (Gibco \#10828-028) (-20 C).

- Non-Essetial Amino Acids $100 \times$ (Gibco) $\left(4^{\circ} \mathrm{C}\right)$.

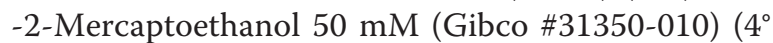

C).

-Penicillin (10.000U/ml)/Streptomycin (10.000 ug/ $\mathrm{ml})(100 \mathrm{X})$

(Gibco \#15140-122) (-20C).

-GlutaMAX 200 mM (100X) (Gibco \#35050-038)

$\left(-20^{\circ} \mathrm{C}\right)$.

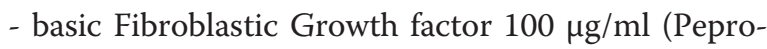
tech) $\left(-20^{\circ} \mathrm{C}\right)$.

-Human albumin 20\% (Grifols) (RT). $300 \mathrm{ml}$

- Knockout DMEM $250 \mathrm{ml}$

$-10 \%$ Knockout Serum Replacement $30 \mathrm{ml}$

$-1 \times$ Non-Essetial Amino Acids $3 \mathrm{ml}$

$-50 \mu \mathrm{M}$ 2-Mercaptoethanol 0,3 ml

$-1 \times$ penicillin/Streptomycin $(100 \mathrm{U} / \mathrm{ml}, 100 \mu \mathrm{g} /$

ml) $3 \mathrm{ml}$

-1× GlutaMAX $200 \mathrm{mM} 3 \mathrm{ml}$

$-10 \mathrm{ng} / \mathrm{ml}$ basic Fibroblastic Growth factor $30 \mu \mathrm{l}$

-Human albumin 20\% $7.5 \mathrm{ml}$

The use of conditioned media for hESC or hiPSC on matrigel is essential. To make conditioned media, simply add HEUS media to irMEFS over night and the next day fliter through a millipore $0.45 \mathrm{uM}$ filter onto cells.

\section{BOX 2}

Plating irHFF or irMEF cells

The day before plating ES[4] cells seed irradiated feeders HFF (ATCC) on gelatinized plates. For a $100 \mathrm{~mm}$ plate: 
1. Gelatinize by adding $5 \mathrm{ml} /$ dish $0.1 \%$ gelatin in water (Chemicon). Incubate at least $30 \mathrm{~min}$ at $37^{\circ} \mathrm{C}$ (you can also leave the plate with gelatin overnight at $37^{\circ} \mathrm{C}$ ). Aspirate the gelatin solution and let the plate dry under the hood. 2. Plate $4 \times 10^{6}$ cells $/ 100 \mathrm{~mm}$ plate in DMEM +10\%FBS, $1 \times$ Glutamax, $1 \times$ Pen/Strep.

\section{Plating hESC or hiPSC by trypsinization on matrigel coated plates}

When the colonies get big enough and start to touch other colonies is time to passage them. Coating of plates using 1:15 diluted Growth Factor Reduced (GFR) matrigel (from BD) in Knockout DMEM is done the day before at $4^{\circ} \mathrm{C}$ and has been described previously [19].

- Aspirate media and wash cells with PBS.

- Add $1 \mathrm{ml}$ of 0,05\% trypsine-EDTA and incubate at $37^{\circ} \mathrm{C}$ for $2-5$ minutes.

- Add $9 \mathrm{ml}$ of HUES media and resuspend the cells:

- If you want a single cell suspension: perform a complete trypsinization and pipette up and down several times before plating.

- Plate the cells at the desired dilution, usually 1:6 dilution.

- Don't change the media the following 48 hours after plating.

- Change the media daily. Warm up just the needed media each time.

\section{PROCEDURE}

\section{Maintaining ESC and iPSC in culture using matrigel or} feeder layers

For hESC or iPSC on feeder layers, pluripotent cells can be trypsinized and then separated during analysis based on Forward Scatter (FSC). To maintain the line, cells must be passaged using a scrapper via a video screen linked to a stereomicroscope. Pluripotent cell colonies are scrapped off the feeder layer, collected and split into waiting feeder layers no more than 1:3 (for ES cells) and 1:10 (for iPS cells). For hESC or hiPSC maintained on matrigel trypsinization is used (see box 2).

CRITICAL STEP: Proper cultivation of pluripotent stem cells to keep cells healthy is essential because it can affect growth rates dramatically, which can be seen by some cell cycle analyses.

\section{Assessment of cell cycle profile and apoptosis by Flow Cytometry from the same sample \\ TIMING 3 hours.}

We use the Invitrogen Click IT EdU kit for detection of $\mathrm{S}$ phase with a modified protocol to give quicker and easier to achieve results. We have tested many DNA dyes and DAPI has been found best DNA staining for pluripotent cells, especially when samples are left overnight at $4^{\circ} \mathrm{C}$ (Figure 1). For assessment of apoptosis we use the MitoProbe DiLC assay kit (M34151). Pluripotent cells can be split after EdU treatment into two tubes, one for EdU assessment of cell cycle profile and the other for assessment of apoptosis by DiLC (Mitochondrial membrane potential). In that way both measures can be made from the same sample.

\section{BOX 3}

\section{Getting the most out of your cell cycle flow cytometry} analysis

In addition to information about the percent of cells in each of the phases of the cell cycle from EdU/DAPI staining, extra information about the proliferative state of the cells can be gleaned from the analysis.

(A). To the right of the percentages of each phase in Flow Cytometry analysis histograms there are two values (Figure 2). The first is the mean intensity of signal from DAPI and the second is the intensity of signal for EdU. The value for EdU is an indication of how fast the cells are proliferating because the faster they proliferate the more EdU they will absorb. Therefore this number can act as a guide to the $S$ phase percentages when assessing how fast they are proliferating. Be careful to ensure to use the same concentration of EdU (10 uM) for the same time period (45 minutes exposure to cells) with the same density of pluripotent cells for all experiments. (B). A second piece of information that can be taken from the cell cycle Flow Cytometry analysis is a clear separation of the 3 phases; G1, S and G2/M phases (Figure 2). A clear separation is desirable with the $\mathrm{S}$ phase high above the other phases. If this is not the case it means that the EdU staining did not work or the pluripotent cells are not healthy and not proliferating normally (they could be quiescent. Ensure to check that the pluripotent cells are healthy before experiments.

\section{Assessment of cell cycle profile by flow cytometry}

CRITICAL STEP Make sure pluripotent cells are between 40-60\% confluent in all experiments because cell density affects the final results (Figure 2).

1. Label the cells with EdU substrate by adding $10 \mathrm{ul}$ of $10 \mathrm{mM}$ EdU solution to $10 \mathrm{mls}$ of culture medium in $10 \mathrm{~cm}$ plate of cells (a 1:1000 dilution) to make a $10 \mathrm{uM}$ final working concentration and incubate for 45 minutes at $37^{\circ} \mathrm{C} 5 \% \mathrm{CO} 2$. See Table 1 . 2. We have found that for pluripotent cells leaving the EdU for 45 minutes is optimal[4]. 


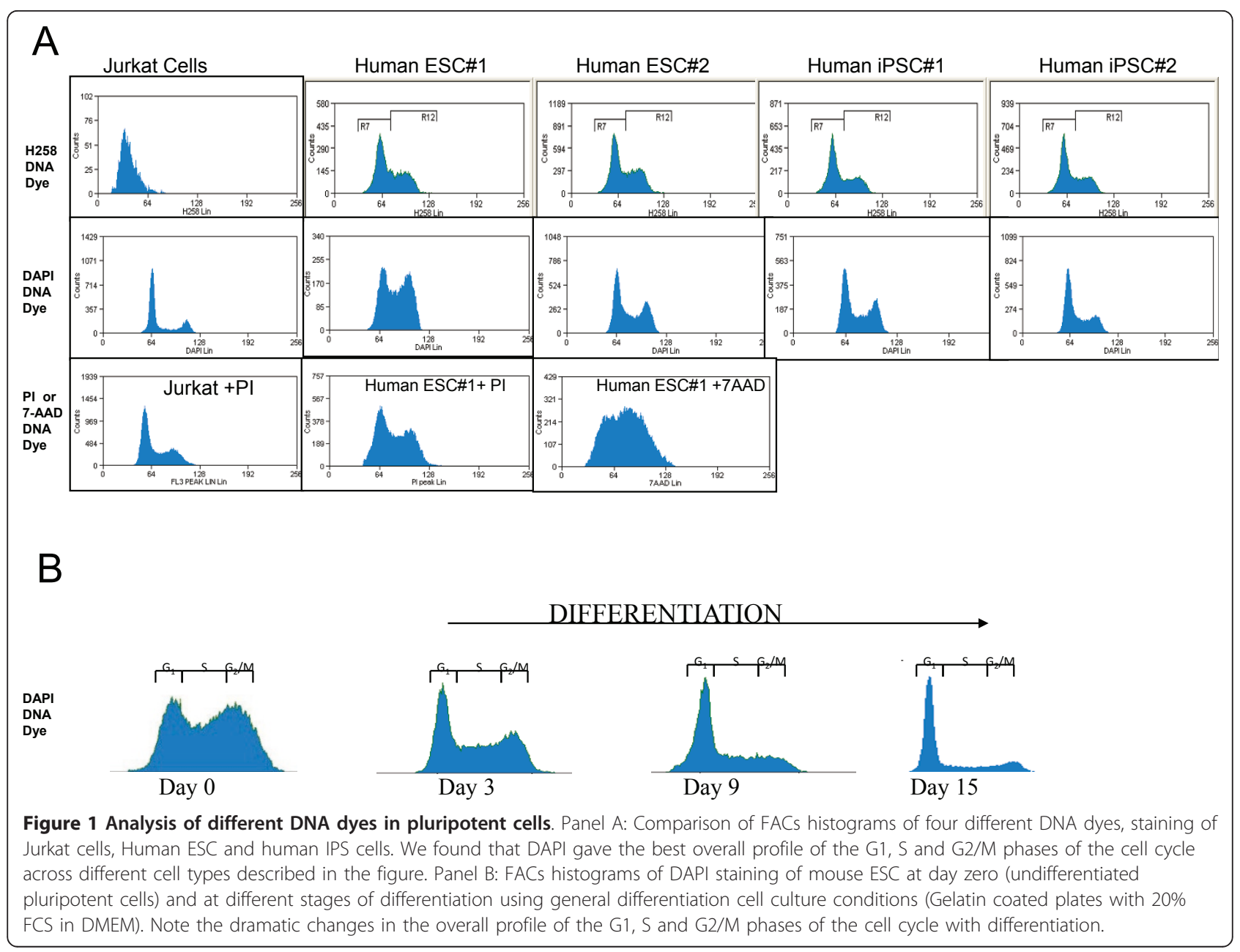

3. Wash cells once with PBS and harvest cells by trypsinization for pluripotent cells cultured on matrigel or by scrapping the cells off the feeder layer to get pure pluripotent cell population. Timing 10 minutes.

4. Wash the cells again in PBS and transfer cells to Flow Cytometry tubes. Spin down at $1500 \mathrm{rpm}$ for 2 minutes to form pellet. Remove PBS simply by turning tube upside down into a waste container with one quick movement, drying the edges on paper to remove drops at edge of tube. This leaves approximately $50 \mathrm{ul}$ of PBS in the FACS tube.

CRITICAL STEP: Tapping the tube only once upside is essential otherwise the cells will slide out.

CAUTION: EdU cocktail breaks down GFP signal that may be expressed in genetically modified pluripotent cells being used, but not the Alexa fluor dyes. Therefore consider adding an anti-GFP AlexaFluor-488 conjugated antibody step to cells before labelling with EdU cocktail to retrieve the GFP signal.
5. Add $100 \mu \mathrm{l}$ of Click IT fixative for 15 minutes R/ $\mathrm{T}$ and mix well by vortex.

6. Wash once $3 \mathrm{mls}$ of PBS and pellet cells again at $1500 \mathrm{rpm}$ for 2 minutes and discard wash buffer by inverting the Flow Cytometry tube as described above. 7. Permeabilize the cells by adding $100 \mu \mathrm{l}$ of saponin based wash buffer for 30 minutes $\mathrm{R} / \mathrm{T}$.

8. Wash with $3 \mathrm{mls}$ of saponin based wash buffer and pellet cells again.

9. Add Click IT reaction cocktail and add $500 \mu \mathrm{l}$ per Flow Cytometry tube and incubate for $30 \mathrm{~min}$ utes $\mathrm{R} / \mathrm{T}$ in the dark.

10. Wash once with PBS, pellet cells and add DAPI solution and incubate overnight at $4^{\circ} \mathrm{C}$ and analyse the following day for best results or leave at $4^{\circ} \mathrm{C}$ for at least $2 \mathrm{~h}$ for immediate FACS analysis.

CRITICAL STEP: We have tried different DNA dyes (PI, Hoechst33342, Click-iT EdU Cell Cycle 633-red, $7 \mathrm{AAD}$, and in our hands the best cell cycle profiles in 


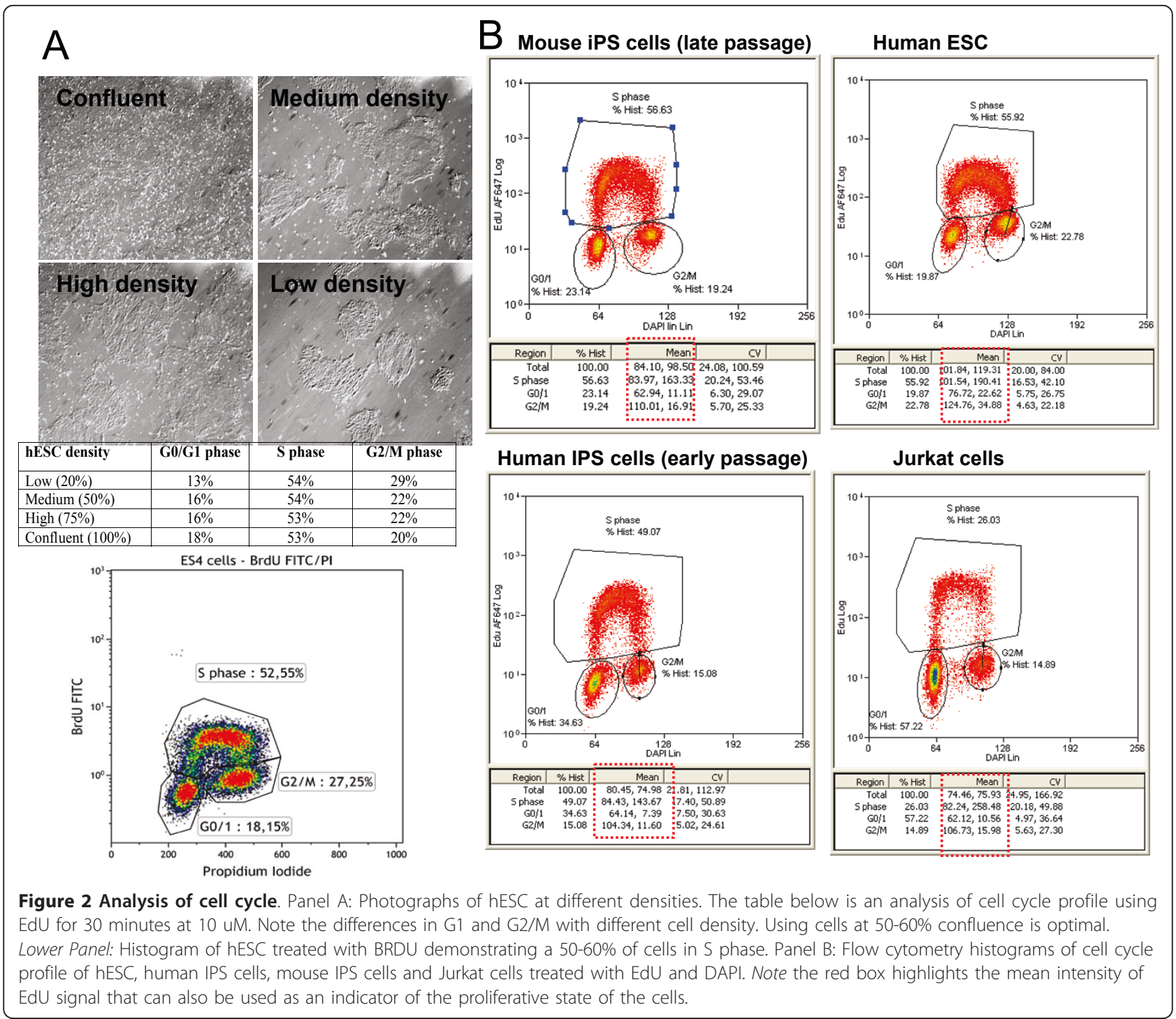

terms of lowest coefficients of variation for the G0/1 peak came up when using DAPI.

11. Assess a minimum of 10000 events at levels described in Table 2.
CRITICAL STEP: Check to ensure that you flow cytometry machine has PMT detectors that are Hamamatsu -15 , which are very sensitive. If not higher powers of 100-200 $\mathrm{mW}$ may be needed to detect DAPI.

Table 1 Modified working volumes for Click IT cocktail for EdU analysis of S phase.

\begin{tabular}{lccc}
\hline Reaction components for Click IT cocktail & \multicolumn{2}{c}{ Number of reactions } \\
\hline & $\mathbf{2}$ & $\mathbf{5}$ & $\mathbf{1 0}$ \\
\hline 10X Click-IT Reaction Buffer & $87.5 \mathrm{ul}$ & $219 \mathrm{ul}$ & $438 \mathrm{ul}$ \\
\hline CuSO4 & $20 \mathrm{ul}$ & $50 \mathrm{ul}$ & $100 \mathrm{ul}$ \\
\hline Fluorescent dye & $5 \mathrm{ul}$ & $12.5 \mathrm{ul}$ & $25 \mathrm{ul}$ \\
\hline 10X Reaction buffer additive & $10 \mathrm{ul}$ & $25 \mathrm{ul}$ & $50 \mathrm{ul}$ \\
\hline Water & $877.5 \mathrm{ul}$ & $2193.5 \mathrm{ul}$ & $4387 \mathrm{ul}$ \\
\hline TOTAL volume & $1 \mathrm{ml}$ & $2.5 \mathrm{ml}$ & $5 \mathrm{ml}$ \\
\hline
\end{tabular}


Table 2 MoFlo Instrument Settings the Flow Cytometry machine for detection of GFP, EdU and DAPI signals.

\begin{tabular}{lll}
\hline Laser & Excitation wavelength \& power & Band Pass Filters used for collection of emitted fluorescence (wavelength/power) \\
\hline Blue & $488 \mathrm{~nm}$ at $30 \mathrm{mWatts}$ & Green emission - 530/30 (from anti-GFP/Alexa Fluor 488) \\
\hline Ultra violet & $351 \mathrm{~nm}$ at $20 \mathrm{mWatts}$ & Blue emission - 450/65 (from DAPI) \\
\hline Red & $633 \mathrm{~nm}$ at $35 \mathrm{mWatts}$ & Red emission - 670/20 (from Alexa Fluor 647 azide linked to EdU) \\
\hline
\end{tabular}

\section{Assessment of Apoptosis using DiLC by Flow Cytometry analysis}

We have assessed two methods for measuring apoptosis in pluripotent cells including DiLC and Annexin V. We found that DiLC gave the best results. Annexin V is not suitable for trypisination of pluripotent cells because it causes false positives (see Figure 3 and Table 3 ).

TIMING 2 hours.

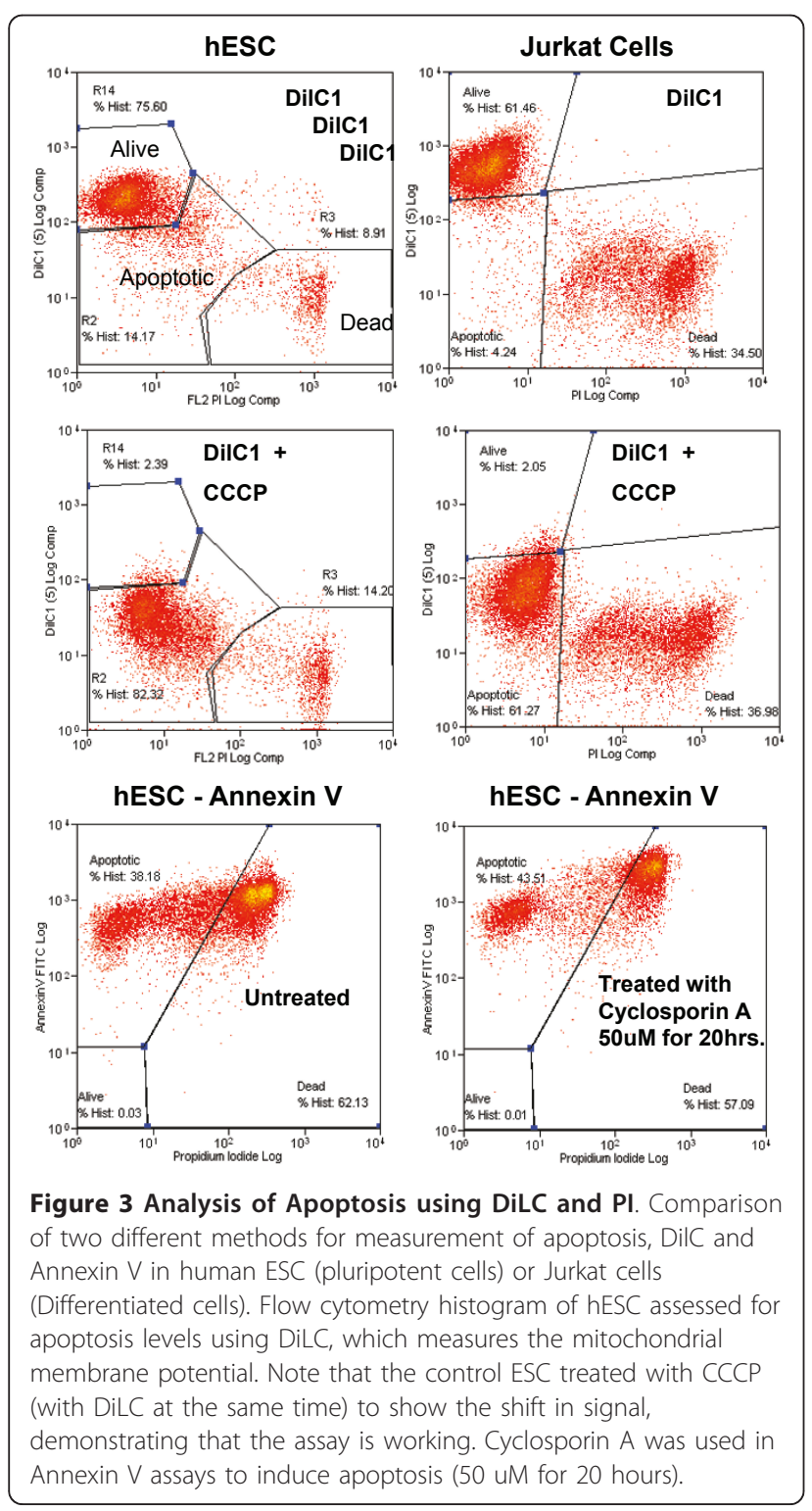

12. The other sample of pluripotent cells split from the original is used to assess levels of apoptosis.

13. Use the MitoProbe DiLC Assay Kit for Flow Cytometry (M34151) from Invitrogen to measure mitochondrial membrane potential.

14. Tripsinize or scrape pluripotent cells from plate and pellet cells by centrifuge and place in prewarmed $\left(37^{\circ} \mathrm{C}\right) \mathrm{PBS}$.

CRITICAL STEP Maintain the cells at $37^{\circ} \mathrm{C}$ at all times in a water bath for stable membrane potential. Having access to a water bath in the flow cytometry machine room is advised.

15. Wash cells again in $1 \mathrm{ml}$ pre-warmed PBS in Flow Cytometry tubes and pellet.

16. For control tubes add $1 \mathrm{uL}$ of $50 \mathrm{mM} \mathrm{CCCP} \mathrm{and}$ incubate cells at $37^{\circ} \mathrm{C}$ for 5 minutes.

CRITICAL STEP: Including a CCCP (it is a metabolic inhibitor) control is essential to clearly define within the histogram analysis the cut-off between the apoptotic and alive populations in the first experiments and to determine that the apoptosis assay is working. Adding CCCP causes loss of mitochondrial membrane potential (MMP) and should cause a shift of cells out of the top left where alive cells can be found (Figure 3).

17. Add $5 \mathrm{uL}$ of $10 \mu \mathrm{M}$ DilC (can be added at same time with CCCP for controls) and incubate at $37^{\circ} \mathrm{C}$, $5 \% \mathrm{CO}_{2}$ for 30 minutes).

18. Wash with $3 \mathrm{mls}$ of pre-warmed PBS and pellet cells and discard wash by tipping once and drying edges (50 uL of solution is left with this method).

19. Resuspend cells with $100 \mathrm{uL}$ of propidium iodide (PI) solution and incubate for 15 minutes at $37^{\circ} \mathrm{C}$.

20. Proceed to analyser to assess percent of cells apoptotic/alive/dead (see Figure 3).

21. Assess a minimum of 10,000 events.

CRITICAL STEP: samples must be analysed immediately to ensure the membrane is preserved. Heating the DAKO MoFlo flow cytometer tubing to $37^{\circ} \mathrm{C}$ is recommended. With the MoFlo, the sample port can be set at any temperature with a range $0^{\circ} \mathrm{C}-40^{\circ}$. Because the $37^{\circ}$ $\mathrm{C}$ is important in order to maintain the MMP, taking 
Table 3 MoFlo Instrument Settings for detection of DilC and PI signal.

\begin{tabular}{lll}
\hline Laser & Excitation wavelength \& power & Band Pass Filters used for collection of emitted fluorescence (wavelength/power) \\
\hline Blue (PI) & $488 \mathrm{~nm}$ at $30 \mathrm{mWatts}$ & $\begin{array}{l}\text { Orange emission - 580/30 (from PI) } \\
\text { Red emission - 670/30 (from Pl) }\end{array}$ \\
\hline Red (DilC) & $633 \mathrm{~nm}$ at $35 \mathrm{mWatts}$ & Red emission - 670/20 (from DilC) \\
\hline
\end{tabular}

advantage of this feature in your flow cytometry machine will help maintain valid results.

\section{Western Blot methodology}

We include a list of antibodies that have been tried and tested for detecting cell cycle proteins and apoptosis proteins in pluripotent cells (Table 4). These selected antibodies, of some of the main cell cycle proteins, work with resolving SDS gels of 4-12\% using between 10-15 $\mu \mathrm{g}$ of total protein unless specified in table 4. If non resolving gels are used then use $8 \%$ gels for $\mathrm{Rb}, \mathrm{p} 107$, cdc27 and MDM2, which are $80 \mathrm{Kda}$ or bigger proteins and $12 \%$ SDS gels for all others. See Figure 4 for an example of the expected results for pluripotent cells

Table 4 Tested and working antibodies for analysis of cell cycle and apoptosis by western blot methodology.

\begin{tabular}{|c|c|c|}
\hline $\begin{array}{l}\text { Antibody } \\
\text { name }\end{array}$ & $\begin{array}{l}\text { Company and Cat } \\
\#\end{array}$ & $\begin{array}{l}\text { Dilution and expected size } \\
\text { (KDa). }\end{array}$ \\
\hline P53 & $\begin{array}{l}\text { sc-126(DO-1) } \\
\text { mouse }\end{array}$ & 1:1000 5\%milk/TBS. $53 \mathrm{KDa}$ \\
\hline P19ARF & R562 Abcam Rabbit & $\begin{array}{l}\text { 1:1000 5\%milk/TBS } 25 \text { Kda (30- } \\
50 \mu \mathrm{g})\end{array}$ \\
\hline P16INK4a & M-156 (sc-Rabbit) & 1:1000 5\%milk/TBS 16 Kda \\
\hline $\mathrm{Rb}$ & C15 (sc rabbit) & 1:1000 5\%milk/TBS 105 KDA \\
\hline P107 & C18 (sc Rabbit) & 1:1000 5\%milk/TBS. $107 \mathrm{KDa}$ \\
\hline Cyclin A & C19 (sc-rabbit) & 1:1000 5\%milk/TBS 54 Kda \\
\hline Cyclin A1 & $\mathrm{H}-230$ (sc rabbit) & 1:1000 5\%milk/TBS 54 Kda \\
\hline Cyclin A2 & $\begin{array}{l}\text { Epitomics E399 } \\
\text { (rabbit) }\end{array}$ & 1:500 5\%milk/TBS 54 Kda \\
\hline Cyclin B1 & Sc-245 (mouse) & 1:1000 5\%milk/TBS 60 Kda \\
\hline Cyclin D1 & $\mathrm{H}-295$ (sc rabbit) & 1:1000 5\%milk/TBS $34 \mathrm{KDa}$ \\
\hline Cyclin D2 & M20 (sc rabbit) & 1:1000 5\%milk/TBS $34 \mathrm{KDa}$ \\
\hline Cyclin E & M20 (sc rabbit) & 1:1000 5\%milk/TBS $53 \mathrm{KDa}$ \\
\hline E2F1 & Sc-251 (sc mouse) & 1:1000 5\%milk/TBS 55 KDa \\
\hline P21CIP & F5 (sc mouse) & 1:1000 5\%milk/TBS $21 \mathrm{KDa}$ \\
\hline P27KIP & $\begin{array}{l}\text { (M-197) sc776 } \\
\text { rabbit }\end{array}$ & 1:1000 5\%milk/TBS $27 \mathrm{KDa}$ \\
\hline CDK4 & C22 (sc rabbit) & 1:1000 5\%milk/TBS $34 \mathrm{KDa}$ \\
\hline CDK2 & $\mathrm{H}-298$ (sc rabbit) & 1:1000 5\%milk/TBS $34 \mathrm{KDa}$ \\
\hline PCNA & PC-10 (sc. Mouse) & 1:1000 5\%milk/TBS $36 \mathrm{KDa}$ \\
\hline MDM2 & $\begin{array}{l}\text { Abcam 2A10 } \\
\text { (mouse) }\end{array}$ & $\begin{array}{l}\text { 1:1000 5\%milk/TBS } 80 \mathrm{KDa}(30-50 \\
\mu \mathrm{g})\end{array}$ \\
\hline $\begin{array}{l}\text { Cleaved } \\
\text { Casapse } 3\end{array}$ & $\begin{array}{l}\text { Cell sign (rabbit) } \\
\text { \#9664 }\end{array}$ & 1:1000 5\%milk/TBS $18 \mathrm{KDa}$ \\
\hline $\mathrm{Cdc} 27$ & C4 (sc mouse) & 1:1000 5\%milk/TBS 102 KDa \\
\hline
\end{tabular}

TIMING: 1 week.

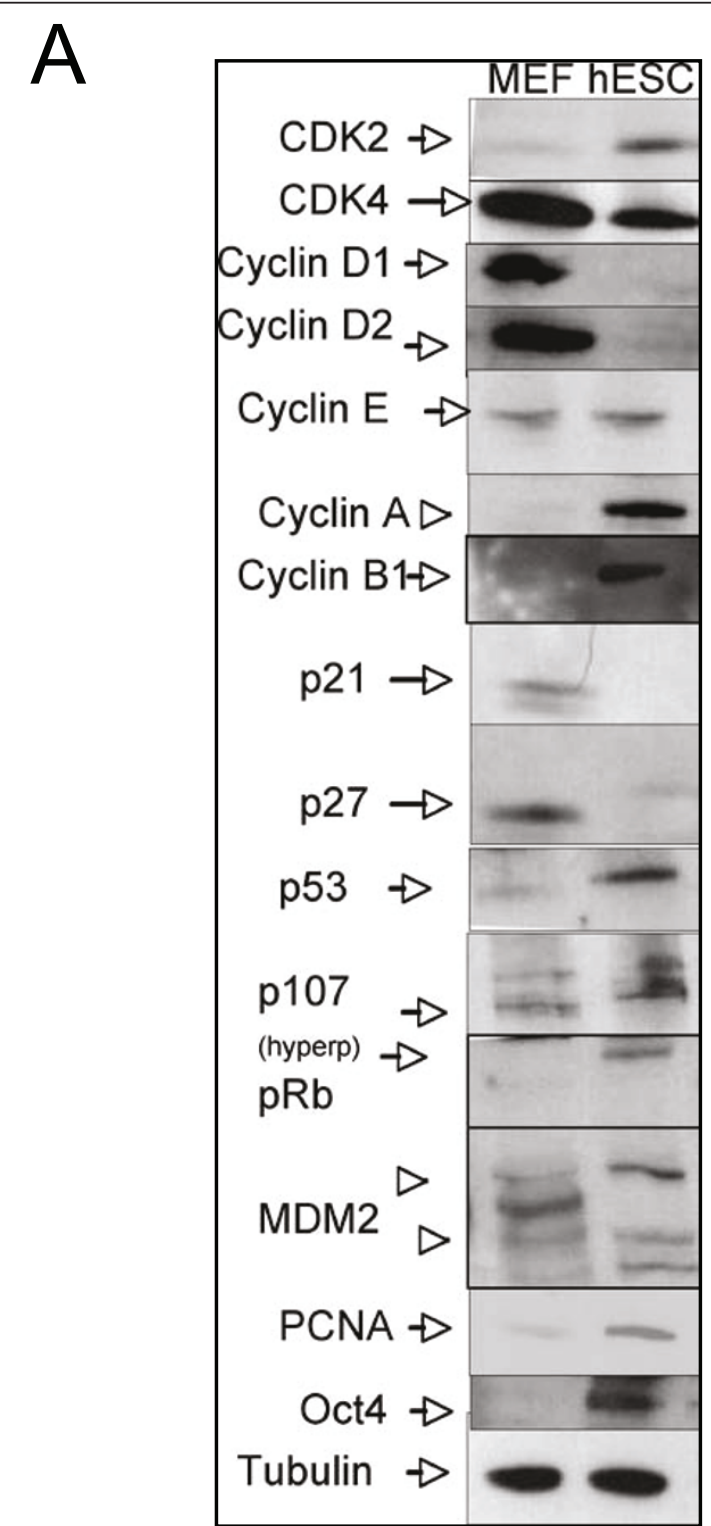

Figure 4 Western blot analysis of cell cycle proteins. Western blot of fourteen cell cycle antibodies described in table 4 using irradiated MEFs as a control and undifferentiated human ESC protein. Alpha-tubulin used as a loading control and Oct4 is used to determine pluripotent state. Note: a comprehensive analysis such as this one can be achieved in one week. sc: Santa Cruz; Cell Sign: Cell Signal antibodies. 
using some of these antibodies. Using 10 well gels, up to four lysates can be loaded twice on one gel, with protein molecular weight markers and four gels run at the same time (two gels per container). Each membrane can be blotted twice for two different antibodies from different species (i.e. first with mouse antibodies, and developed and then re-blotted with the rabbit primary antibodies and developed again) and a final time for alpha tubulin as a loading control (not listed). Therefore, up to 16 antibodies can be tested from the 4 gels using between 40 and $60 \mu \mathrm{g}$ of total protein. If manipulating a cell cycle gene by gain of function (cDNA) or loss of function (shRNA), then protein lysates can be run alongside the ESC lane to determine the overall effect on core cell cycle protein expression levels.

\section{Discussion}

Accurate cell cycle analysis has to be based on data from cells handled in a manner in which the least variation between experiments occurs. In our hands the reliability and validity of the described method for measurement of apoptosis and cell proliferation in the same sample is very good. In the past other methods have been developed to measure cell proliferation that provide an alternative approach (see trouble shooting table 5). Specifically, the use of other DNA dyes may improve the method in different laboratories with different machines. Other DNA specific dye, such as propidium iodide (PI) can be added to the labelled cells for two-parameter analysis of EdU. We settled on DAPI (overnight at $4^{\circ} \mathrm{C}$ ) giving the most reliable results. In our experience with EdU stainings for flow cytometry analysis, the CVs have remained low and reproducible with DAPI staining and not 7-AAD (a modification from the kit). To achieve this we recommend that factors such as cell culture conditions are maintained well, exposure time of substrate and concentration (as well as storage of substrate) is maintained well and that cell density is equal between experiments (see Figure 1). Other methods for assessment of cell cycle have been published before. Krishan and Hamelik have modified the EdU procedure as an alternative method to the one we have described (20). In comparison to our method, the method involves a more laborious step of isolation of cell nuclei. Moreover, the requirements and complexicity of the method is more demanding. Therefore, to maintain simplicity and ease in use of the protocol with low CVs we prefer to use DAPI staining with EdU, and give the same results compared to using BRDU (see Figure 2).

We chose EdU click IT kit over standard BRDU staining for $\mathrm{S}$ phase analysis because it gave reliable results and was quicker to complete with the same results (Figure 2). It is important to note that the Click-it method breaks down GFP signal so we recommend to use an anti-GFP antibody to recognize GFP expression, since it uses copper sulfate and ascorbate to develop a signal. Other methods have suggested to fix the cells in dilute paraformaldehye which keeps the GFP intact prior to staining (21). We agree that fixing cells with dilute paraformaldehyde can preserve the GFP signal, however in our hands, using an anti-GFP AlexaFluor-488 antibody, a flurochrome that is not degraded during the reaction cocktail step, helps to retrieve the GFP signal, a significant advantage with pluripotent cells that are so often hard to infect/transfect. Given that ESC are notoriously difficult for gain and loss of gene function studies, retrieving the GFP signal with an Alexaflour 488 GFP antibody, gives an advantage to attaining the best results form flow cytometry work.

Flow Cytometry machines available to researchers from lab to lab will vary and that different machines will require different power settings. The machine used in this protocol is a High Performance MoFlo Cell sorter. The MoFlo is equipped with 3 lasers, an Innova 90C UV laser from Coherent, a red diode $635 \mathrm{~nm}$ and Lytcyt200s $488 \mathrm{~nm}$ solid-state laser. The PMT detectors used are Hamamatsu -15; this is the most sensitive model and therefore low power levels at $30 \mathrm{~mW}$ are used. If we work with 100-200 $\mathrm{mW}$ of power the signal would be out of range. The best resolution of DNA signals may require more power using different machines; however, this would depend on DNA dye used. For example Hoechst dye exclusion assays to identify the side population in a bone marrow just require 20-30 $\mathrm{mW}$ of UV power using a machine not equipped with a Hamamatsu-15 detector.

Table 5 Troubleshooting

\begin{tabular}{ll}
\hline Step Problem & Possible reason and solution \\
\hline Low number of cells in S Phase & EdU substrate incubation too short or batch of substrate used too many times. Use fresh aliquoted \\
& EdU and incubate $15-30$ minutes longer. \\
No distinct G1/S/G2M phases & Cells not healthy or DAPI staining not working. Check that cells look healthy before starting \\
& experiment and leave DAPI staining overnight at $4^{\circ} \mathrm{C}$ (in the fridge). Also consider using a modified \\
method using Hamelik and Krishan protocol by lysing cells (Hypotonic solution) for 1 minute followed & by centrifugation and then using EdU reaction (Click iT) [20]. \\
DilC \% apoptosis lower than & Check with CCCP control there is a shift in DilC positive cells to negative. Keep cells at 37 ${ }^{\circ} \mathrm{C}$ at all \\
expected or not working. & times throughout the procedure and analyse immediately following PI staining.
\end{tabular}


The faster cells proliferate when the cells are exposed to BrdU or EdU for a fixed amount of time means more cells labeled in late $S, G_{2}$ or $M$ phases. The main data from EdU staining is $S$ phase percentages but we thought to also highlight that the mean intensity of signal can also be used a secondary guide as well. When working with a fixed amount of time and EdU concentration as recommended in our protocol, the difference in the EdU Signal to Noise ratio $(\mathrm{S} / \mathrm{N})$ can be directly related with how fast they are growing. The more time exposure and the more concentration of EdU the higher the $\mathrm{S} / \mathrm{N}$ ratio and for this reason it is important to use pluripotent cells at around $50-60 \%$ confluency, the same concentration of EdU and also the same incubation time for all the treated samples. We recommend that $10 \mathrm{uM} \mathrm{EdU}$ and $45 \mathrm{~min}-$ utes to be used across the field for pluripotent cells. In that way coefficient of variation can be calculated intralaboratory for many different pluripotent cell lines and we have found very little variation between experiments when this protocol is followed correctly.

\section{Conclusions}

At the end of the protocol a comprehensive analysis of the percent of cells in $G_{0} / G_{1}$ phase, $S$ phase and $G_{2} / M$ phase should reveal an expected percentages of cells in each phase as: $15 \% / 65 \% / 20 \%+/-5 \%$, respectively. Changes greater than $5 \%$ in the $G_{1}$ or $G_{2} / M$ phases between samples of interest are considered significant. Further evidence of an effect on cell cycle can be done by performing a proliferation growth curve to show differences more clearly. In our experience, differences even less than $10 \%$ in $\mathrm{S}$ phase can be seen in proliferation curves maintained for over 2 to 3 weeks. Western Blot analysis should reveal a protein expression for the main cell cycle proteins as seen in Figure 4. Apoptosis measurements by FACs should give a normal range of $70-75 \%$ of cells alive, $20 \%$ in transition and $5-10 \%$ apoptosis using DilC combined with PI methods. Overall, this protocol will give rise to a detailed analysis of the cell cycle and apoptosis status in human and mouse pluripotent cells, offering a standardized approach across the field. For more details of making lentivirus and infection of ESC, please see previous published work from our group (17-19).

\section{Acknowledgements \\ The authors are indebted to Meritxell Carrió for expert assistance with cell culture techniques. Cristina Menchon is partly supported by a pre-doctoral grant from the Spanish Ministry (AP-2004-3523). This work was partially supported by grants from the Fondo de Investigaciones Sanitarias, Insituto Carlos III (P1071209), MICINN, Fundacion Cellex, CIBER, Sanofi-Aventis and the G. Harold and Leila Y. Mathers Charitable Foundation.}

\section{Author details}

${ }^{1}$ Center of Regenerative Medicine in Barcelona, Dr. Aiguader 88, 08003 Barcelona, Spain. ${ }^{2}$ Current Address: Vall d' Hebron Research Institute, Xcelia and Banc de Sang i Teixits, Passeig Vall d'Hebron, 119 - 129, 08035 Barcelona, Spain. ${ }^{3}$ Current Address: Affiliation with Victor Chang Cardiac Research Institute, Lowy Packer Building 405 Liverpool St, Darlinghurst New South Wales 2010, Australia. ${ }^{4}$ Gene Expression Laboratory, Salk Institute for Biological Studies, 10010 North Torrey Pines Rd., La Jolla, California 92037, USA.

\section{Authors' contributions}

MJE designed the overall protocol, wrote the manuscript after obtaining material from all authors. JMAV developed the flow cytometry protocol and performed low cytometry experiments. CM developed and tested the western blot methods. JCIB supervised the project.

All authors have read and approved the final manuscript.

\section{Competing interests}

The authors declare that they have no competing interests.

Received: 19 November 2010 Accepted: 11 April 2011

Published: 11 April 2011

\section{References}

1. Thomson JA, Itskovitz-Eldor J, Shapiro SS, Waknitz MA, Swiergiel JJ, Marshall VS, Jones JM: Embryonic stem cell lines derived from human blastocysts. Science 1998, 282:1145-1147.

2. Takahashi K, Yamanaka S: Induction of pluripotent stem cells from mouse embryonic and adult fibroblast cultures by defined factors. Cell 2006, 126:663-676.

3. Takahashi K, Tanabe K, Ohnuki M, Narita M, Ichisaka T, Tomoda K, Yamanaka S: Induction of pluripotent stem cells from adult human fibroblasts by defined factors. Cell 2007, 131:861-872.

4. Edel MJ, Menchon C, Menendez S, Consiglio A, Raya A, Izpisua Belmonte JC: Rem2 GTPase maintains survival of human embryonic stem cells as well as enhancing reprogramming by regulating p53 and cyclin D1. Genes Dev 2010, 24:561-573.

5. Zhao Y, Yin X, Qin H, Zhu F, Liu H, Yang W, Zhang Q, Xiang C, Hou P, Song $Z$, et al: Two supporting factors greatly improve the efficiency of human iPSC generation. Cell Stem Cell 2008, 3:475-479.

6. Li H, Collado M, Villasante A, Strati K, Ortega S, Canamero M, Blasco MA, Serrano M: The Ink4/Arf locus is a barrier for iPS cell reprogramming. Nature 2009, 460:1136-1139.

7. Kawamura T, Suzuki J, Wang YV, Menendez S, Morera LB, Raya A, Wahl GM, Belmonte JC: Linking the p53 tumour suppressor pathway to somatic cell reprogramming. Nature 2009, 460:1140-1144.

8. Hong H, Takahashi K, Ichisaka T, Aoi T, Kanagawa O, Nakagawa M, Okita K, Yamanaka S: Suppression of induced pluripotent stem cell generation by the p53-p21 pathway. Nature 2009, 460:1132-1135.

9. Marion RM, Strati K, Li H, Murga M, Blanco R, Ortega S, FernandezCapetillo O, Serrano M, Blasco MA: A p53-mediated DNA damage response limits reprogramming to ensure iPS cell genomic integrity. Nature 2009, 460:1149-1153.

10. Utikal J, Polo JM, Stadtfeld M, Maherali N, Kulalert W, Walsh RM, Khalil A Rheinwald JG, Hochedlinger $\mathrm{K}$ : Immortalization eliminates a roadblock during cellular reprogramming into iPS cells. Nature 2009, 460:1145-1148.

11. Savatier P, Lapillonne H, Jirmanova L, Vitelli L, Samarut J: Analysis of the cell cycle in mouse embryonic stem cells. Methods Mol Biol 2002 , 185:27-33.

12. Stead E, White J, Faast R, Conn S, Goldstone S, Rathjen J, Dhingra U, Rathjen P, Walker D, Dalton S: Pluripotent cell division cycles are driven by ectopic Cdk2, cyclin A/E and E2F activities. Oncogene 2002, 21:8320-8333.

13. White J, Dalton S: Cell cycle control of embryonic stem cells. Stem Cell Rev 2005, 1:131-138.

14. Becker KA, Ghule PN, Therrien JA, Lian JB, Stein JL, van Wijnen AJ, Stein GS: Self-renewal of human embryonic stem cells is supported by a shortened G1 cell cycle phase. J Cell Physiol 2006, 209:883-893.

15. Kalaszczynska I, Geng Y, lino T, Mizuno S, Choi Y, Kondratiuk I, Silver DP, Wolgemuth DJ, Akashi K, Sicinski P: Cyclin A is redundant in fibroblasts but essential in hematopoietic and embryonic stem cells. Cell 2009, 138:352-365.

16. Faast $R$, White J, Cartwright $P$, Crocker L, Sarcevic B, Dalton S: Cdk6-cyclin D3 activity in murine ES cells is resistant to inhibition by p16(INK4a). Oncogene 2004, 23:491-502. 
17. Tiscornia $G$, Singer $\mathrm{O}$, Verma IM: Design and cloning of lentiviral vectors expressing small interfering RNAs. Nat Protoc 2006, 1:234-240.

18. Tiscornia G, Singer O, Verma IM: Production and purification of lentiviral vectors. Nat Protoc 2006, 1:241-245.

19. Raya A, Rodriguez-Piza I, Navarro S, Richaud-Patin Y, Guenechea G, SanchezDanes A, Consiglio A, Bueren J, Izpisua Belmonte JC: A protocol describing the genetic correction of somatic human cells and subsequent generation of iPS cells. Nat Protoc 2010, 5:647-660.

20. Hamelik RM, Krishan A: Click-iT assay with improved DNA distribution histograms. Cytometry A 2009, 75:862-865.

21. Cappella P, Gasparri F, Pulici M, Moll J: Cell proliferation method: click chemistry based on BrdU coupling for multiplex antibody staining. Curr Protoc Cytom 2008, Chapter 7, Unit 734.

doi:10.1186/1478-811X-9-8

Cite this article as: Edel et al:: A protocol to assess cell cycle and apoptosis in human and mouse pluripotent cells. Cell Communication and Signaling 2011 9:8.

\section{Submit your next manuscript to BioMed Central} and take full advantage of:

- Convenient online submission

- Thorough peer review

- No space constraints or color figure charges

- Immediate publication on acceptance

- Inclusion in PubMed, CAS, Scopus and Google Scholar

- Research which is freely available for redistribution

Submit your manuscript at www.biomedcentral.com/submit 